\title{
STUDY OF METAKAOLIN FIBRE AND POND ASH AS A REPLACEMENT TO CEMENT IN CONVENTIONAL CONCRETE
}

\author{
Brijesh Soni ${ }^{1}$, Ritesh Lahoti ${ }^{2}$ \\ ${ }^{1}$ Student of Final Year (2014) B.E. Civil, SIEM, Nashik, India \\ ${ }^{2}$ Student of Final Year (2014) B.E. Civil, SIEM, Nashik, India
}

\begin{abstract}
Concrete is probably the most extensively used construction material in the world. The addition of mineral admixture and cement has dramatically increased along with the development of concretre industry due to the consideration of cost saving, energy saving, environmental protection and conservation of resources. However, environmental concerns both in terms of damage cost by the extraction of raw materials and carbon dioxide emission during cement manufacture have brought pressures to reduce cement consumption by the use of supplementary materials. So, to minimize the use of cement, there is a constant urge to find alternatives for cement. In recent years, there is an increase in the utilization of Metakaolin Fibre in concrete as replacement to cement by weight. Which has proven an increased compressive strength of atleast 10 to $20 \%$. However, the cost of Metakaolin Fibre is significantly higher than that of cement (3 to 4 times higher). So, taking into consideration the cost component of concrete, Pond Ash/ Fly Ash which is available in abundance and which is very cheap is used along with Metakaolin Fibre in preparation of concrete. The present report deals with the study of compressive strength of M25 grade concrete incorporating different percentage of Metakaolin Fibre by weight of cement along with pond ash. The results of study indicate that the strength of concrete mixes improved by 20-25\% which also mitigate the higher costs required by Metakaolin Fibre.
\end{abstract}

Keywords- Metakaolin Fibre, Pond Ash/ Fly Ash, Compressive Strength, M25 Grade Concrete

\section{INTRODUCTION}

Reinforced concrete has come to stay as the most accepted construction material worldwide. It is a composition of reinforcement and material consisting cement and aggregates of various size and shape. The marine environment, the large numbers concrete structures and other mega structures have suffered from the serviceability and safety.Therefore to make the concrete more durable, stronger and effective structural part hence there is use of these mineral admixtures like Metakaolin Fibre, glass fiber, silica fumes. The strength of concrete depends upon several factors like chemical composition of cement, water-cement ratio, types and amount of the admixtures. The use of Metakaolin in concrete has positive effect on its strength and durability. Metakaolin has also developed the mechanical and physical properties of concrete. Due to this reason the study of Metakaolin support the concrete and its ingredients. The concrete is cured with watering, its compressive strength is determined after 7 days and 28 days and it is up to certain limit, but metakaolin will help in increase in the compressive strength. Metakaolin is cement replacing material which helps the concrete to increase its mechanical and physical properties. Metakaolin is finer than cement and it mainly increase the hydro chloride ion which increases the compressive strength of the concrete. Metakaolin will help in boosting the compressive strength of the concrete, because metakaolin will react with the calcium hydroxide due to this cement compound particles will increase which ultimately results in the increase in the strength of the concrete. Moreover, Pond Ash/ Fly Ash which is readily available, if replaced by weight of cement along with
Metakaolin, will make the concrete economical.While Metakaolin increases the compressive strength and durability, Fly Ash will make the concrete cost effective. This will help our future civil engineers for their effective work and to attain our goal of reducing the cement consumption.

\section{EXPERIMENTAL MATERIALS}

Properties of various materials used in making the concrete (M25) are discussed in the following sections.

\subsection{Cement}

Ordinary Portland cement (OPC) of 53 grade was used for the experimental procedure which was carried out in this project.

\subsection{Metakaolin Fibre}

Metakaolin is a highly efficient pozzolona and reacts rapidly with the excess calcium hydroxide resulting from OPC hydration, via a pozzolonic reaction, to produce calcium silicate hydrates and calcium alumina silicate hydrates. Metakaolin is not a byproduct. It is obtained by the calcinations of pure or refined Kaolinite clay at a temperature between $6500 \mathrm{C}$ and $8500 \mathrm{C}$, followed by grinding to achieve a fineness of $700-900 \mathrm{~m} / \mathrm{kg}$. Metakaolin is a high quality pozzolonic material, which is blended with cement in order to improve the durability of concrete. When used in concrete it will fill the void space between cement particles resulting in a more impermeable concrete.The 
physical and chemical properties of metakaolin, OPC are presented in table below:

Table 1. Properties of OPC and Metakaolin Fibre

\begin{tabular}{|l|l|l|}
\hline Property & $\begin{array}{l}\text { Cement } \\
(\text { OPC) }\end{array}$ & Metakaoline \\
\hline Specific gravity & 3.1 & 2.5 \\
\hline Mean grain size $(\mu \mathrm{m})$ & 22.5 & 2.54 \\
\hline Specific area $(\mathrm{cm} 2 / \mathrm{g})$ & 3250 & $150000-180000$ \\
\hline Color & Dark grey & Ivory to cream \\
\hline Silicon dioxide $(\mathrm{Si09})$ & 20.25 & $60-65$ \\
\hline Aluminum oxide $(\mathrm{A} 1203)$ & 5.04 & $30-34$ \\
\hline Iron oxide $(\mathrm{Fe} 203)$ & 3.16 & 1.00 \\
\hline Calcium oxide $(\mathrm{CaO})$ & 63.61 & $0.2-0.8$ \\
\hline Magnesium oxide $(\mathrm{MgO})$ & 4.56 & $0.2-0.8$ \\
\hline Sodium oxide $(\mathrm{Na} 20)$ & 0.08 & $0.5-1.2$ \\
\hline Potassium oxide $(\mathrm{K} 2 \mathrm{O})$ & 0.51 & - \\
\hline
\end{tabular}

\subsection{Fine Aggregate (Sand)}

River sand was used which was silt free and satisfying all requirement of Indian Standard.

\subsection{Coarse Aggregate}

Crushed angular granite metal from a local source was used as coarse aggregate of size 20 to $25 \mathrm{~mm}$.

\subsection{Water}

Water is an important ingredient of concrete, as it actively participates in the chemical reaction with cement. The strength of cement concrete comes mainly from the binding action of the hydrated cement gel and excess water causes voids and reduces strength of concrete. Hence the potable tap water has been used for casting.

\subsection{Pond Ash}

The following physical, Index \& Other property is expected for PA Pond Ash (PA) will be generated and collected at Ash Pond located in the vicinity of the plant. This will be the mixture of Fly Ash and Bottom Ash in wet condition.

Table 2. Physical Properties

\begin{tabular}{|l|l|l|l|l|l|}
\hline $\mathrm{G}$ & WL\% & \%Passing through $75 \square \mu$ & IS Classification & Yd( KN/m³), Max at W\% & $\phi \mathrm{p}($ Comp \& Sat) \\
\hline 2.7 & 77 & 8.6 & SP-SM & 7.7 AT 64.7\% & 34 \\
\hline
\end{tabular}

Table 3 Chemical properties

\begin{tabular}{|l|l|l|l|l|l|l|l|}
\hline $\mathrm{SiO}_{2}$ & $\mathrm{AL}_{2} \mathrm{O}_{3}$ & $\mathrm{Fe}_{2} \mathrm{O}_{3}$ & $\mathrm{MnO}$ & $\mathrm{MgO}$ & $\mathrm{CaO}$ & $\mathrm{K}_{2} \mathrm{O}$ & $\mathrm{Na}_{2} \mathrm{O}$ \\
\hline $23-73$ & $13-26$ & $4-10.9$ & $\mathrm{Bd}-0.5$ & $0.1-0.7$ & $0.1-0.8$ & Bd-0.56 & Bd-0.3 \\
\hline
\end{tabular}

Bd- Below detection

\section{MIX DESIGN}

The Mix Design was designed for M25 grade as per IS: 10262-1982 manually and same design was used in preparation of test samples. The table below shows Mix Design proportion.

Table 4: Mix Proportion For M25 concrete

\begin{tabular}{|l|l|l|l|l|}
\hline \multirow{2}{*}{ Grade of concrete } & \multicolumn{4}{|l|}{ Quantity per $\mathbf{~ m}^{\mathbf{3}}$ of concrete in $\mathbf{k g}$} \\
\cline { 2 - 5 } & Water(lit) & Cement $($ OPC 53) & FineAggregate & CoarseAggregate \\
\hline \multirow{3}{*}{ M25 } & 197 & 386 & 810.6 & 950 \\
\cline { 2 - 5 } & 0.51 & 1 & 2.1 & 2.46 \\
\hline
\end{tabular}

\section{EXPERIMENTAL PROCEDURE}

A. Various tests on aggregates were performed to calculate the hardness, size, durability, specific gravity, impact value, etc. such as Specific Gravity, Fineness Modulus, Shape Test (Flakiness and Elongation Index), Aggregate Impact Value Test.

B. After collecting the materials as specified in the mix design, the mixture was mixed in Mechanical Mixer for 2.5 to 3.5 minutes till the whole mixture looks uniform.
C. Slum Cone Test was performed to check the workability of prepared mix.

D. Dimension of the mould was $15 \mathrm{~cm} \times 15 \mathrm{~cm} \times 15 \mathrm{~cm}$. The moulds were kept in Accelerated Curing Tank for 3 hours at $100^{\circ} \mathrm{C}$ and then kept as it is for 24 hours. For each type of combination of PA and Metakaolin 3 cubes were casted.

E. The compressive strength of cubes was measured in CTM ( Compressive Tenting Machine), the loading rate was 5.2 $\mathrm{kg} / \mathrm{cm}^{2}$ and the load was applied gradually. 


\section{RESULTS}

Table 5: Pond Ash ( $0 \%$ replacement by weight of cement)

\begin{tabular}{|l|l|l|}
\hline $\begin{array}{l}\text { Sr. } \\
\text { NO. }\end{array}$ & $\begin{array}{l}\text { METAKAOLIN } \\
(\%)\end{array}$ & $\begin{array}{l}\text { COMPRESSIVE } \\
\text { STRENGTH } \\
\left(\mathrm{N} / \mathrm{mm}^{2} @ 28 \text { days }\right)\end{array}$ \\
\hline 1 & 0 & 34.53 \\
\hline 2 & 5 & 34.4 \\
\hline 3 & 10 & 37.5 \\
\hline 4 & 15 & 35.65 \\
\hline 5 & 20 & 35.92 \\
\hline 6 & 25 & 36.00 \\
\hline
\end{tabular}

Table 6: Pond Ash ( $5 \%$ replacement by weight of cement)

\begin{tabular}{|l|l|l|}
\hline Sr. No. & $\begin{array}{l}\text { METAKAOLIN } \\
(\%)\end{array}$ & $\begin{array}{l}\text { COMPRESSIVE } \\
\text { STRENGTH } \\
\left(\mathrm{N} / \mathrm{mm}^{2} @ 28 \text { days }\right)\end{array}$ \\
\hline 1 & 5 & 35.66 \\
\hline 2 & 10 & 40.56 \\
\hline 3 & 15 & 39.42 \\
\hline 4 & 20 & 37.41 \\
\hline 5 & 25 & 35.12 \\
\hline
\end{tabular}

Table 7: Pond Ash ( $10 \%$ replacement by weight of cement)

\begin{tabular}{|c|c|c|}
\hline $\begin{array}{l}\text { Sr. } \\
\text { No. }\end{array}$ & METAKAOLIN (\%) & $\begin{array}{l}\text { COMPRESSIVE } \\
\text { STRENGTH } \\
\left(\mathrm{N} / \mathrm{mm}^{2} @ 28 \text { days }\right)\end{array}$ \\
\hline 1 & 5 & 38.56 \\
\hline 2 & 10 & 44.76 \\
\hline 3 & 15 & 41.12 \\
\hline 4 & 20 & 40.02 \\
\hline 5 & 25 & 39.82 \\
\hline
\end{tabular}

Table 8: Pond Ash (15\% replacement by weight of cement)

\begin{tabular}{|l|l|l|}
\hline $\begin{array}{l}\text { Sr. } \\
\text { No. }\end{array}$ & METAKAOLIN (\%) & $\begin{array}{l}\text { COMPRESSIVE } \\
\text { STRENGTH } \\
\text { (N/mm }{ }^{2} \text { @ 28 days) }\end{array}$ \\
\hline 1 & 5 & 36.12 \\
\hline 2 & 10 & 37.76 \\
\hline 3 & 15 & 38.23 \\
\hline 4 & 20 & 33.18 \\
\hline 5 & 25 & 34.64 \\
\hline
\end{tabular}

Table 9: Pond Ash (20\% replacement by weight of cement)

\begin{tabular}{|l|l|l|}
\hline $\begin{array}{l}\text { Sr. } \\
\text { No. }\end{array}$ & METAKAOLIN (\%) & $\begin{array}{l}\text { COMPRESSIVE } \\
\text { STRENGTH } \\
\text { (N/MM }\end{array}$ @ 28 days) \\
\hline 1 & 5 & 32.06 \\
\hline 2 & 10 & 35.25 \\
\hline 3 & 15 & 34.28 \\
\hline 4 & 20 & 32.56 \\
\hline 5 & 25 & 29.76 \\
\hline
\end{tabular}

\section{CONCLUSION}

Based on above study the following observations are maderegarding the properties and behavior of concrete on partial replacement of fine aggregate by Metakaolin Fibre and Pond Ash:

[1] The addition of metakaolin has increased the compressive strength of traditional concrete.

[2] In this study, maximum compressive strength is obtained at $10 \%$ replacement by weight of cement with both metakaolin fibre and pond ash.

[3] There is use of the metakaolin concrete for making high performance concrete using standard concrete mix and obtained strength of high performance concrete.

[4] The concrete curing is done sufficiently then no cracks of creep and shrinkage are observed on the concrete surface.

[5] The concrete is durable and makes the proper bonding of the concrete ingredients with each other at standard watercement ratio.

[6] The metakaolin concrete has full properties to resist the external atmospheric reactions which have adverse affect on the concrete strength.

\section{ACKNOWLEDGMENT}

The authors are thankful to Prof. K. T. Phalak, Prof. Abhijeet Pawar (Lab Incharge), Prof. K. L. Bidkar (HOD), SIEM, Nashik.

\section{REFERENCES}

[1]. VikasSrivastava, Rakesh Kumar and V.C. Agarwal, "Metakaolin inclusion: Effect on mechanical properties of concrete", Civil Engg. Department, SHIATS (Formerly AAI-DU), Allahabad-211007, UP, India.

[2]. Vinod B. Shikhare, L. G. Kalurkar, "Combine Effect of Metakaolin, and Steel Fiber on Mechanical Properties of High Strength Concrete", PG Student, Department of Civil Engineering, MGM's Jawaharlal Nehru Engineering College, Aurangabad/Dr. B.A. Marathwada University, Aurangabad-431003, Maharashtra, India.

[3]. Civil Engineers Hand Book, P.N.Khanna

[4]. Reference Book on Concrete Technology, M.S.Shetty

[5]. Reference Book on Concrete Technology, S. Santhkumar

[6]. IS 516: 1959, Indian standards method of test for strength of concrete.

[7]. IS 5816-1999 Indian Standard Splitting Tensile Strength of Concrete Methods of Test.

[8]. IS 383-1963 Specification for coarse and fine aggregates from natural sources of concrete Bureau of Indian Standard.

[9]. IS 9013-1978 Method of making, curing and determining compressive strength of Accelerated-Cured concrete test specimens, Bureau of Indian Standard

[10]. IS 456:2000 Code of practice for plain and reinforced concrete.

[11]. IS 2386:1963, (Part I to Part VIII) Indian standards methods of test for aggregate for concrete.

[12]. IS 10262:1982, Indian standards recommended Guidelines for concrete mix design. 